\title{
TRANSFORMATION OF THE BANKING SECTOR OF UKRAINE: REASONS AND CONSEQUENCES
}

\author{
Myroslava Khutorna \\ $\mathrm{PhD}$, associated professor \\ Czerkasy Scientific and Educational Institute, Banking Department \\ Banking University
}

\begin{abstract}
:
This paper is devoted to the consideration of the preconditions and results of the banking sector of Ukraine transforming, its influence on the sector's productivity, stability and significance for the real economy. It's grounded that banking sector of Ukraine has seriously weakened its potential for the economic development stimulation. On the one hand, due to the banking sector clearance from the bad and unscrupulous banks the system has become much more sensitive to the monetary instruments and its state is going to be more predictable and better controlled. But on the other hand, massive banks' liquidations have caused the worsening of the confidence in financial system and radical increasing of the market concentration the highest degree of which is observed in the householders' deposit market.
\end{abstract}

Keywords: banking sector, concentration, effectiveness, profitability.

JEL Class: G21, D43.

\section{INTRODUCTION}

The current economic environment in Ukraine is the most complicated for the domestic economic entities (and banks as well) that they've ever faced with. The main catalysts of this economic depression were a political crisis in Ukraine 
2013 and war aggression from Russia, but the prime causes are the massive structural imbalances of the whole Ukrainian economy that were being accumulated during last ten years. Also should be mentioned deep and old (even ,ancient") problems of Ukraine: corruption, shadow capital flows, poor judicial system. All these have caused ineffective economic system, restrained the force of the market mechanisms and increased instability, crisis susceptibility. At the same time, economic environment influences on the state of the financial system and the capability of the financial market for intermediation. National Bank of Ukraine has summarized the main factors that contain the financial sector development in Ukraine, that are as follows:

1) the financial institutions that don't execute intermediary and that is why have become the source of the systemic risks;

2) the poor standards for bank solvency and liquidity management;

3 ) the trespass of the operations with insiders;

4) an ineffective banking and financial intermediary supervision that fails to prevent risks [Conception 2015: 4-5].

The last option had been additionally worsen by the worldwide tendency of the destructive deregulation of the financial sector in early 2000s and we agree with H. Soto [Soto 2008: 305] and Unkovs'ka T. [Unkovs'ka and Demchuk 2013: 8] who define it as one of the crisis's preconditions.

In order to solve these problems in 2015 the regulators of the financial market initiated the working out and the realization of the Integrated Program of the Financial Sector Development in Ukraine, that is expected to be finished by 2020 . The first stage of this program means the clearance of the financial market from the financial intermediaries that don't meet the requirements and aren't willing. While passing through this stage one should consider the peculiarity of the financial market - any unoccupied market share, arised for the liquidation of some financial institutions, will immediately be redistributed among others institutions of the higher social ratings. That's why an active clearance of the financial sector can lead to the critical increasing of the market concentration and system risk intensification.

Should be mentioned, that financial sector of Ukraine is bank oriented, so the main threat for the financial system stability goes from the risks of the banking sector. So this paper is dedicated to the researching of the transforming process of the banking sector of Ukraine. The main purpose of the paper is to consider the influence of the current transforming processes in banking sector of Ukraine on its functionality. While preparing these materials we researched the contribution of the banking sector of Ukraine to the real economy; estimated its concentration level due to its transforming; emphasized the riskiest aspects of the present stage of the banking sector of Ukraine development. 


\section{BANKING SECTOR OF UKRAINE AS A FACTOR OF THE ECONOMIC GROWTH}

The effectiveness of the banking system and a bank as well is always under the active research and the global financial crisis 2008 newly actualized this topic. Sony Kapoor [2009: 8] explicates an effective banking system in a laconic but system way and characterizes it as follows:

- it is effective at reallocating capital from savers to investors;

- it does this efficiently with low deadweight costs to the economy;

- it allocates risks from those who do not have the capacity to manage it to those who do;

- it is resilient to shocks and provides shock absorption capacity for the economy;

- it does not depend on regular does of tax payer subsidy.

We should also stress that the essential factor for the banking system effectiveness is the banking regulation, especially effective system of the prudential supervision for the financial stability providing. We think this factor is to be included as a characteristic of the effective banking system. Should be mentioned that the faults in the banking supervision by the National Bank of Ukraine by many experts is considered as the main factor of the financial crisis 2008 in Ukraine, which results haven't been solved yet. Firstly, we mean foreign currency mortgage loans (especially for the householders) that had been applied no restrictions by the National Bank of Ukraine until the crisis began. Consequently, it caused tremendous delays in loan paybacks, because of the three times devaluation of the national currency, that resulted in almost total insolvency.

The effective banking system incites the capital allocation among the economic agents through the consumers of the financial services, causes the intensification of their activity. As a result, it increases market capacity provided by the solvent demand and provokes the economic growth.

While comparing the dynamics of the banks' assets with other economic indicators we can observe that Ukrainian banking sector doesn't essentially impact on the domestic retail trade which is the reflection of the inner business activity (Fig. 1). The volumes of the retail trade exceeded the import only in 2012-2013, that makes us conclude ineffectiveness of the national banking sector to promote domestic production. And what is more, it has very weak influence on the real sector of economy development. According to the official statistical data the share of the banks' loans in the investments projects financing is no more than $10 \%$. At the end of 2016 it's only $1,16 \%$ of the total banks assets that are used for the project realization. Unfortunately, it can't be explained by the crisis consequences, because the banking sector of Ukraine for all 26 years 
of its existence and development has never been actively involved in the financing of the vitally important sectors of economy and their modernization. In Ukraine it is traditionally made by the own resources of the enterprises.

But at the same time banks of Ukraine use the accumulated deposits as a financial support for the insiders' business. It is about almost all big banks of Ukraine, that obviously negatively influenced on the financial stability of the banking sector and financial system as well.

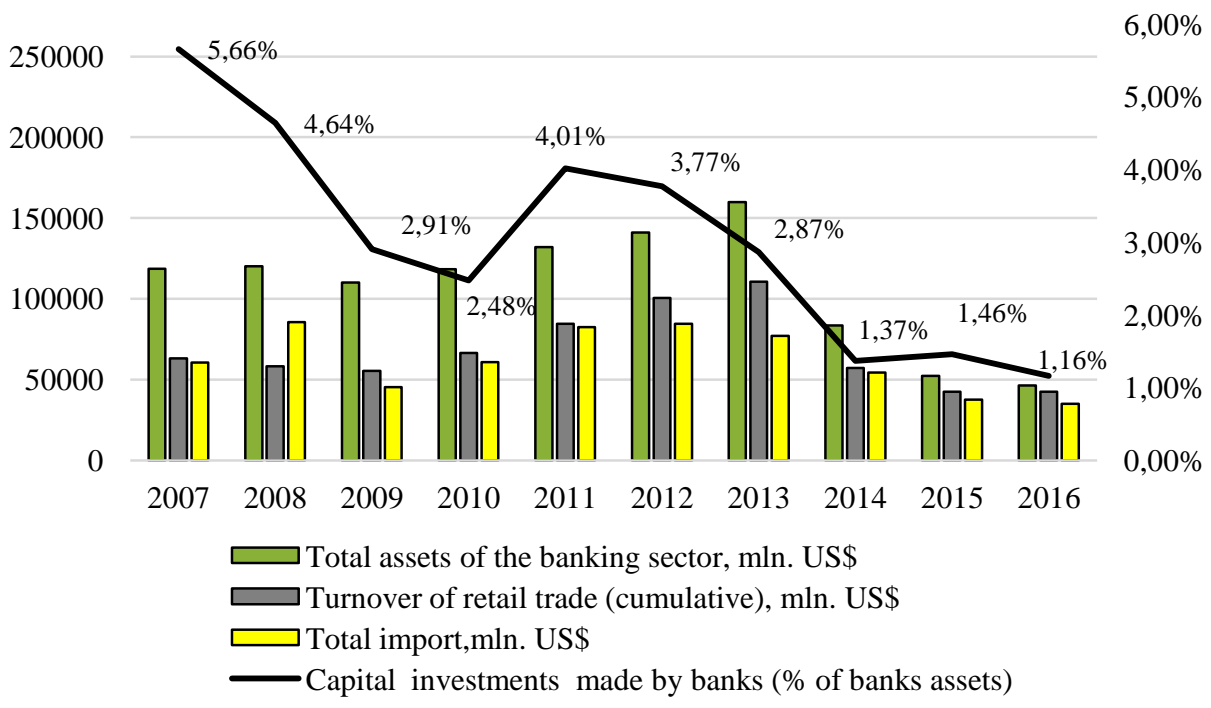

Figure 1.The comparison of the financial and nonfinancial sector of Ukraine's economy during 2007-2016

Source: own study based on the data of the State Statistics Service of Ukraine, Statistical Information (Import (mln. US\$)), Export(GDP (mln. US\$)) (official website); National Bank of Ukraine, Statistics, The Main Indicators of the Activity of Banks of Ukraine (official website), Turnover of retail trade (mln. Hrv).

Since 2013 there has been radical annual decrease of all economic indicators and for now we are observing a destructive compression of the banking sector. Should be mentioned, that banks' assets estimated in Hrv have fairly stable dynamics and it is absolutely controversial to that in USD. The last one is more essential because Ukrainian banking sector as a whole economy is deeply dependent on the foreign currency - the share of the banks with foreign ownership in the share capital is $56 \%$ and $50 \%$ of the total banks assets are formed in foreign currency. 
Another threatening feature of the domestic banking sector is the lack of confidence. National Bank's of Ukraine latest estimations have concluded that for the end of the III $^{\text {rd }}$ quarter 2016 above 287 bill. Hrv (11,5 bill. US\$) or $28 \%$ of the money supply are outside the deposit corporations. It's the result of the distrust of the society in the financial institutions as well as in the state police in general. It should be accented that the only real institutional investor on the financial market of Ukraine is a bank that is why the state of the banking system is a determinant factor for the whole market.

Ought to be mentioned, that the current functioning of the national banking sector is characterized by the credit restriction policy (Fig. 2). The decrease of the banking loans impacts on the increasing of the cash and securities (mainly domestic state bonds).

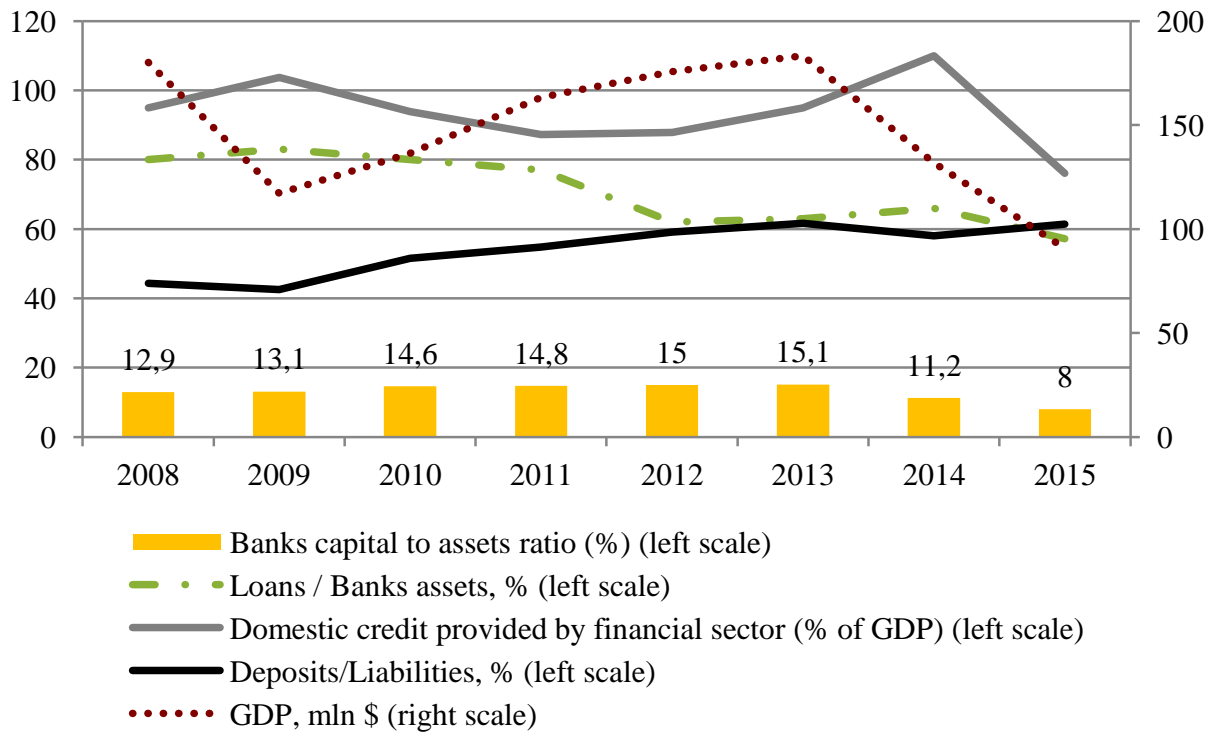

Figure 2. Indicators of the economic significance of the banking sector of Ukraine during 2008-2015

Source: own study based on the data of the World Bank, Indicators, Financial Sector (Domestic credit provided by financial sector (\% of GDP), Bank capital to assets ratio (\%), Economy \& Growth (GDP (current US\$) (official website); National Bank of Ukraine, Statistics, The Main Indicators of the Activity of Banks of Ukraine (official website).

At the same time the domestic credit provided by the financial sector of Ukraine (\% of GDP) changes in a range from 76\% to $110 \%$ during $2008-2015$. Taking into consideration the dynamics of the GDP and its rapid fall since 2013 
the essential meaning of the mentioned above index for Ukraine is not higher than $90 \%$. Comparing it with the other countries and economic units can be concluded that the domestic financial sector is almost two times weaker in funds providing the economic agents that in the developed countries. Another problem is a law level of the indicator "Banks capital to assets ratio" (8\% at the end of the 2015 while the minimal required is 10\%) that prevents banking business intensification until recapitalization.

Summarizing it up we consider that the banking sector of Ukraine has a law ability to stimulate economic development by the financing the economic agents' demand for the resources. It becomes more complicated because of the insufficient level of the „Banks capital to assets ratio”. That's why it can't be solved without the regulator's interference for the problems' revealing and elimination. In Ukraine it's the function of the National Bank of Ukraine.

\section{THE CONCENTRATION LEVEL OF THE BANKING SECTOR OF UKRAINE}

The political crisis 2013 had been transformed into deep economic crisis, that is still in ,development" and has revealed all weaknesses of the national banking system, that are: imperfect credit risk evaluation system and management totally; distorted measurement of the assets fair value; essential share of the bad loans; law level of capitalization. So, in 2014 Ukrainian banking sector was replete by bad assets and felt the results of the deep depression, uncertain future and total distrust in the government agencies, National Bank of Ukraine and all financial institutions as well. All these have caused the necessity of the National Bank of Ukraine intervention for the clearance of the banking sector from the insolvent and unscrupulous banks. As a result, during 2014-2015 the number of the licensed and active banks decreased from 180 to 117 and for the $1^{\text {st }}$ of December 2016 there were 98 licensed banks. So, during last two years 82 banks of Ukraine or $46 \%$ of the total number were liquidated.

We agree that the banking sector of Ukraine is ripe for its clearance from the unscrupulous banks, the great amount of which was caused by the ineffective regulation of the National Bank of Ukraine. But, the liquidation of the 82 banks is a strong test for the whole financial system and stimulates extra fall of the consumer confidence in banking industry and in other financial intermediaries. We think that the grave disadvantage of the current process of the banking sector of Ukraine clearance is the deficiency of the defined consequences of this transformation. In order to prevent social disturbance because of massive banks' liquidation National Bank of Ukraine must systematically analyze and publicize the following information to the participants of the financial market: 
1) how the outback of the banks' number influences on the concentration level of the whole industry; 2) how the clearance of the banking sector affects on the banks' functioning as a paying agents; 3) the increase of the system risks probability because of the financial stability decline.

That's why it's important to research how the current reforming of the banking industry of Ukraine works on its functionality and whether it will cause its monopolization on the part of the biggest banks.

Should be mentioned, that there are diverse opinions on the results of the increasing banking sector concentration. Its positive influence on the industry effectiveness was researched by Tirole [1988], Hay [1991], Berger et al. [2003]. They accented that the concentration can increase the banks' profitability for the industry's scope, better price control and deeper diversification that is accessible for big banks. The researches held after crisis 2008 [Laeven et al. 2014: 1-33] proved the increasing of the system risks because of the intensive growth of the big banks, that requires the obligatory regulatory authorities involvement. In particular, the scientists substantiate the necessity for the providing some additional regulative norms for such banks, especially the aspects of the capitalization and measures to reduce banks' involvement in market-based activities and organizational complexity.

Concerning Ukraine, we should note that a high level of corruption forces to estimate economic results of the active redistribution of the banking market in favor of the biggest banks. One of the widely used indicators of the market concentration is Herfindahl-Hirschman index [Hirschman 1964: 761-762] that is used by the authorities for the antimonopoly policy conducting of different countries for monitoring the concentration level of a market. The threshold quantity of this indicator differs in various economies in accordance to the level of the economic development and national interests. HHI is calculated by squaring the market share of each firm competing in a market, and then summing the resulting numbers:

$$
H H I=\sum_{i=1}^{n} s_{i}^{2}
$$

$s_{i} \quad-$ the market share of the $i$ firm,

$n \quad-$ the total number of firms.

For the estimation of the banking market concentration HHI can be calculated by the aggregated banking indices (total assets, equity, loan portfolio, liabilities) as well as by detailed indices (corporate loans, deposits etc.). Due to the methodology of the Federal Trade Commission's Bureau of Competition a market is defined as competitive if $H H I<1500$; moderate concentrated if 
$1500<\mathrm{HHI}<2500$; highly concentrated if $\mathrm{HHI}>2500$. In EU its key points are 1000 and 2000.

Another indicator is $n$-firm Concentration Ratio that is calculated by summing the market shares of the biggest $\mathrm{n}$ companies on a market:

$$
C R_{n}=\sum_{i=1}^{n} s_{i}
$$

$s_{i} \quad$ - the market share of the $i$ firm,

$n$ - the number of the biggest firms, that are sorted by their market share.

The most popular indices are $C R 3, C R 4, C R 5, C R 8$ i $C R 10$. The degree of the concentration is law if $0 \%<C R_{n}<50 \%$, moderate if $50 \% \leq C R_{n}<80 \%$ and high if $80 \% \leq C R_{n}<100 \%$. In contrast to $H H I, C R_{n}$ allows to monitor the changes that take place among the market leaders. Concerning the basic indices for calculating $C R_{n}$ they can be aggregated and detailed as well.

These two indicators were used for estimation the concentration degree of the banking sector of Ukraine and we have proved that the liquidation of the 82 banks during last two years has greatly impacted on it. What about $H H I$ calculated by the total assets and total capital didn't revealed any serious threats for the national banking industry (Tab. 1).

Table 1. HHI for the banking sector of Ukraine in 2010-2016

\begin{tabular}{|c|c|c|c|c|c|c|c|}
\hline Index & 01.01 .2011 & 01.01 .2012 & 01.01 .2013 & 01.01 .2014 & 01.01 .2015 & 01.01 .2016 & 01.10 .2016 \\
\hline \multicolumn{7}{|c|}{ Calculated by the Total Assets (\% Market Share) } \\
\hline HHI & 407 & 426 & 471 & 517 & 565 & 910 & 954 \\
\hline \multicolumn{7}{|c|}{ Calculated by the Total Capital (\% Market Share) } \\
\hline HHI & 500 & 484 & 449 & 464 & 718 & 837 & 876 \\
\hline \multicolumn{7}{|c|}{ Calculated by the Loans to the Nonfinancial Corporations (\% Market Share) } \\
\hline Calculated by the Loans to the Householders (\% Market Share) \\
\hline HHI & 511 & 535 & 533 & 552 & 651 & 1001 & 1036 \\
\hline HHI & 585 & 555 & 571 & 694 & 829 & 1238 & 1311 \\
\hline Calculated by the Funds of the Nonfinancial Corporations (\% Market Share) & \\
\hline HHI & 437 & 378 & 394 & 356 & 487 & 802 & 802 \\
\hline Calculated by the Funds of the Householders (\% Market Share) \\
\hline HHI
\end{tabular}

Source: own study based on the data of National Bank of Ukraine, Statistics, The Main Indicators of the Activity of Banks of Ukraine (official website). 
Though HHI has almost been doubled during 2014-2015, it characterizes bank sector as competitive and not excessively concentrated. But, while researching $H H I$ by the detailed indices (loans to the corporations, loans to the householders, funds of the corporations, funds of the householders) we can determine the riskiest spheres that have developed in the banking sector of Ukraine resulting in National Bank of Ukraine reforms. Especially it concerns to the market of the householders funds. The structural analysis of the $H H I$, calculated by the banks' market shares of the householders funding, defined its doubling during two last years and what's more it was reached due to active position of one bank - PrivatBank. During 2015 PrivatBank has increased its market share on the householders' deposit market from $24 \%$ to $36 \%$ (or from 4.3 bill US\$ to 6.0 bill US\$). It's important to notice that it's not resulted in the activization of the householders as individual investors, but only by the redistribution of the liabilities of the liquidated banks. As there are no additional legislative requirements to those banks that own the third part of the householders' deposit market it courses the rise of the probability of the system risks and worsen the financial stability.

Table 2. $C R n$ for the banking sector of Ukraine in 2010-2016

\begin{tabular}{|c|c|c|c|c|c|c|c|c|}
\hline Index & 01.01 .2011 & 01.01 .2012 & 01.01 .2013 & 01.01 .2014 & 01.01 .2015 & 01.01 .2016 & 01.10 .2016 \\
\hline \multicolumn{7}{|c|}{ Calculated by the Total Assets (\% Market Share) } \\
\hline CR3 & 26,1 & 27,9 & 30,7 & 32,3 & 34,8 & 46,3 & 48,4 \\
\hline CR4 & 31,9 & 32,8 & 35,0 & 36,6 & 39,4 & 50,8 & 53,0 \\
\hline$C R 5$ & 36,8 & 36,6 & 38,6 & 40,0 & 43,4 & 55,0 & 57,0 \\
\hline$C R 8$ & 48,2 & 47,0 & 47,8 & 49,2 & 54,2 & 66,3 & 67,9 \\
\hline$C R 10$ & 53,9 & 52,8 & 52,7 & 54,3 & 59,7 & 73,1 & 74,4 \\
\hline \multicolumn{7}{|c|}{ Calculated by the Total Capital (\% Market Share) } \\
\hline$C R 3$ & 33,4 & 33,5 & 31,9 & 30,6 & 39,8 & 39,2 & 40,8 \\
\hline$C R 4$ & 38,1 & 37,8 & 36,4 & 38,1 & 44,0 & 50,0 & 52,5 \\
\hline$C R 5$ & 42,8 & 41,9 & 40,1 & 42,6 & 48,2 & 59,7 & 60,5 \\
\hline$C R 8$ & 52,8 & 50,4 & 48,1 & 51,5 & 59,0 & 74,9 & 76,7 \\
\hline$C R 10$ & 57,6 & 55,6 & 52,8 & 56,1 & 64,8 & 79,1 & 81,9 \\
\hline
\end{tabular}

Source: own study based on the data of National Bank of Ukraine, Statistics, The Main Indicators of the Activity of Banks of Ukraine (official website).

In order to deepen the conclusions about the degree of the market concentration and its current dynamics we used $C R_{n}$ for TOP-3, TOP-4, TOP-5, TOP-8, TOP-10 banks of Ukraine. The variables for $C R_{n}$ calculation are total assets and total banking capital. The data presented in Tab. 2 assure that 
82 banks' liquidation has lead directly to the biggest banks market shares expansion. The essential changes concern the concentration degree of the banking sector leaders - until 2014 the TOP- 8 formed the group of the moderate concentration level, but since 2015 this group is formed by the TOP-4 banks. So, Ukraine's banking sector passes through significant structural changes, drastic strengthening the market positions of the big banks. At the same time, during all analyzed periods the owner of the biggest market share by the parameter ,total assets" is Privatbank (owns $21 \%$ of the total market), but it takes the $5^{\text {th }}$ place by the share of the total capital. It's an additional proof of its high risk to the financial stability of the whole banking sector of Ukraine.

In conclusion we should notice that the analysis helps us to define the downtrend of the banks number, the concentration degree increasing that has caused the situation when 4 banks of Ukraine control 50\% of the banking market that results in the oligopoly of the banking industry of Ukraine.

\section{THE IMPACT OF THE UKRAINE'S BANKING SECTOR TRANSFORMATION ON ITS ACTIVITY AND PROFITABILITY}

The results of the 1st stage of the banking sector transformation have become apparent since 2015. So, the banks liquidation caused the reduction of the financial resources from $43 \mathrm{mln}$. US\$ in 2014 to $28 \mathrm{mln}$. US\$ in 2016 (Fig. 3). At the same time it is observed the decrease of the average deposit interest rate that can be reasoned by the clearance of the banking sector from the insolvent and unscrupulous institutions and it is an indicator of the banks' bankruptcy risk lessening. But, it has not yet influenced on the average loan interest rate that is still too high and has been increasing (for householders it is about $30 \%$ and for entities $-20 \%$ ). Another unsolved problem is the share of the bad loans that at the end of 2016 is $25 \%$ of the total loans.

One more aspect that is to be researched is the influence of the banking sector's structure changes on its performance. In order to estimate financial results of the bank's activity we use Return on Equity (ROE), Return on Assets (ROA) and Cumulative Return on Equity (CROE), Cumulative Return on Assets (CROA) for the banking sector, that allows to find out the impact of each bank on the sector's productivity. Two time points were chosen as the time horizon for the analysis: 2012 as the beginning of the national economy recovering after the crisis 2008; 2015 - a year of the essential structural changes in banking sector. Should be noticed that since 2009 banking system of Ukraine has been unprofitable (except 2012 and 2013). For plotting the graphs we sorted all licensed banks by the assets decreasing, each bank is marked as its sequence number in a sorted list. 


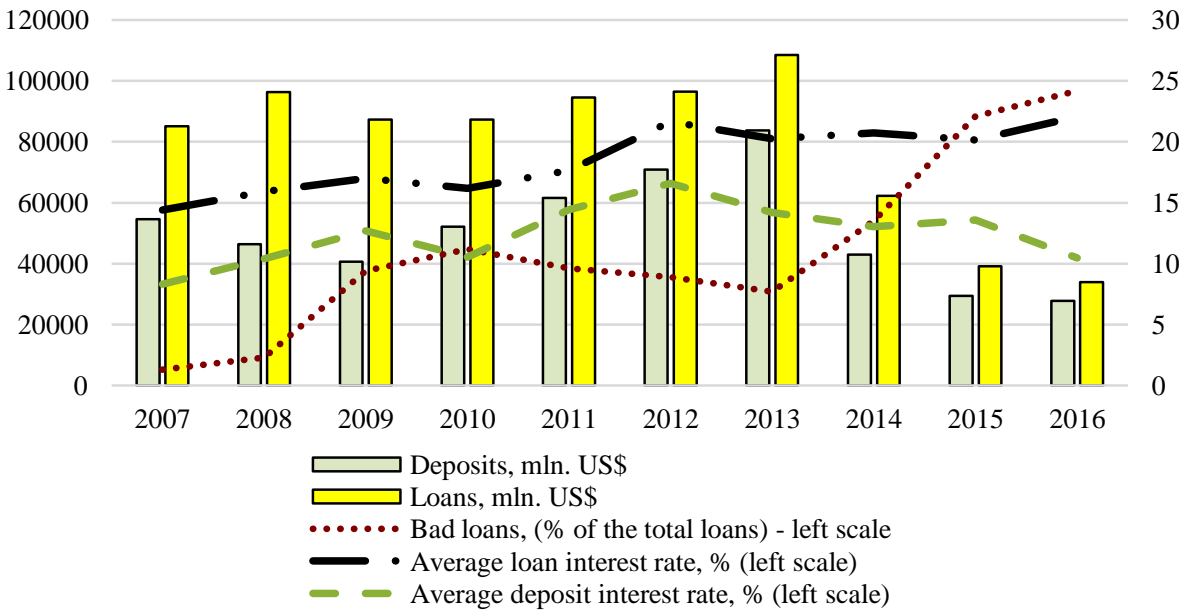

Figure 3.The parameters of the effectiveness of the financial resources reallocation by the banking sector of Ukraine during 2007-2016

Source: own study based on the data of National Bank of Ukraine, Statistics, The Main Indicators of the Activity of Banks of Ukraine (official website).

In 201219 banks of 175 were unprofitable, but it didn't impact on the whole banking sector - CROE and CROA had only positive meanings (Fig. 4, Fig. 5).

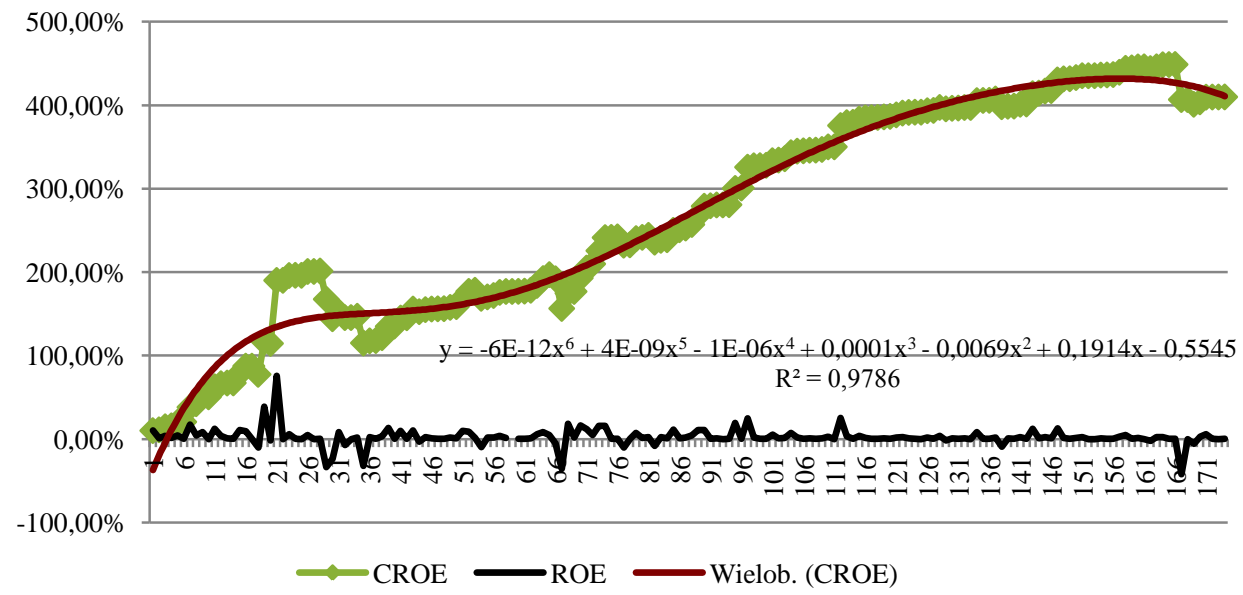

Figure 4. Return on Equity and Cumulative Return on Equity of the banks of Ukraine in 2012

Source: own study based on the data of National Bank of Ukraine, Statistics, The Main Indicators of the Activity of Banks of Ukraine (official website). 
The graph on Fig. 5 distinguished the groups of banks that positively influenced on the profitability of the whole sector (these banks are depicted by arrows) and those banks which performance has a negative impact. Among the last one are small and big banks. It proves that unsatisfactory management is a problem of all banks regardless of their size, but the strongest negative impact on ROA was done by the smallest banks of Ukraine.

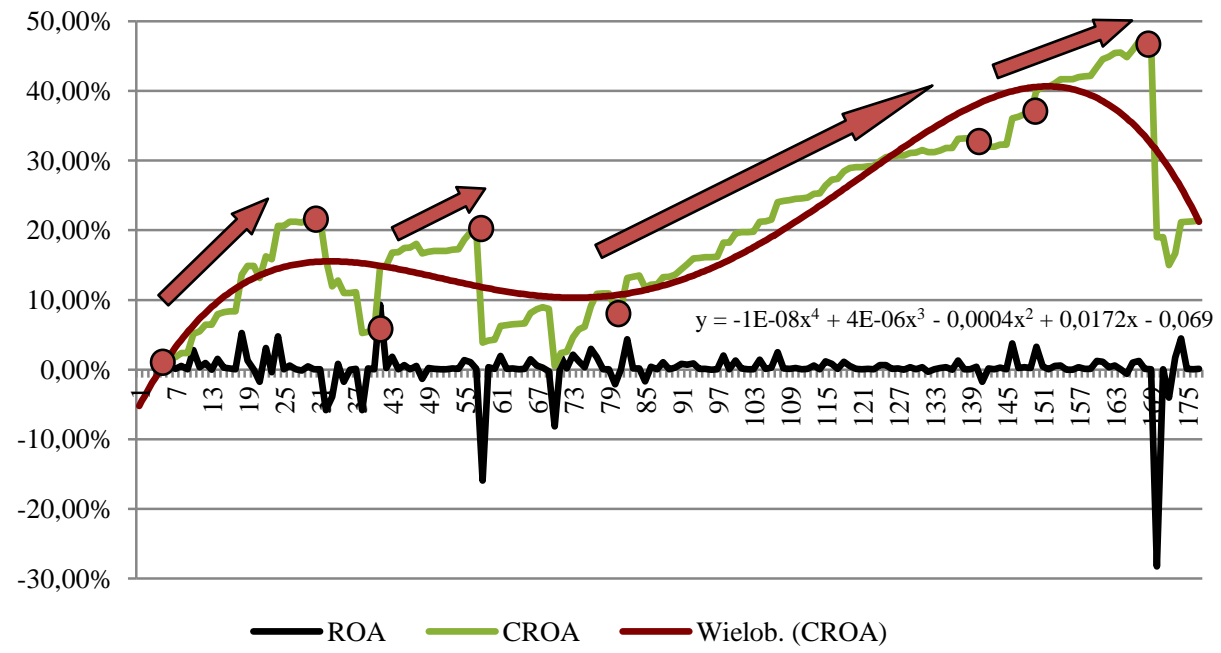

Figure 5. Return on Assets and Cumulative Return on Assets of the banks of Ukraine in 2012

Source: own study based on the data of National Bank of Ukraine, Statistics, The Main Indicators of the Activity of Banks of Ukraine (official website).

42 banks had losses that exceeded aggregate profits of other 67 banks in 2015. As a result the graphs of the CROE and CROA are in the negative semi axis (Fig. 6, Fig. 7). Should be noted that the negative meaning of the CROE is resulted not only by losses, but insufficient capitalization as well.

While researching the effectiveness of the banking sector's clearance in the context of its profitability it is important to take into consideration the state of the banking sector in 2014, as it was the year of the crisis beginning and $1^{\text {st }}$ stage of banking system reforming. Concerning the graphs of CROE and ROE in 2014 they are practically identical to those in 2015, depicted on Fig. 6 .

But the graphs of CROA in 2014 and 2015 are different. Firstly, the CROA of the whole banking sector in 2015 was $-370 \%$ (Fig. 7) and $-1400 \%$ in 2014 (Fig. 8). Secondly, in 2015 there were no banks which losses exceeded their assets, that we define as one of the positive results of the banking clearance initiated by the regulator. 


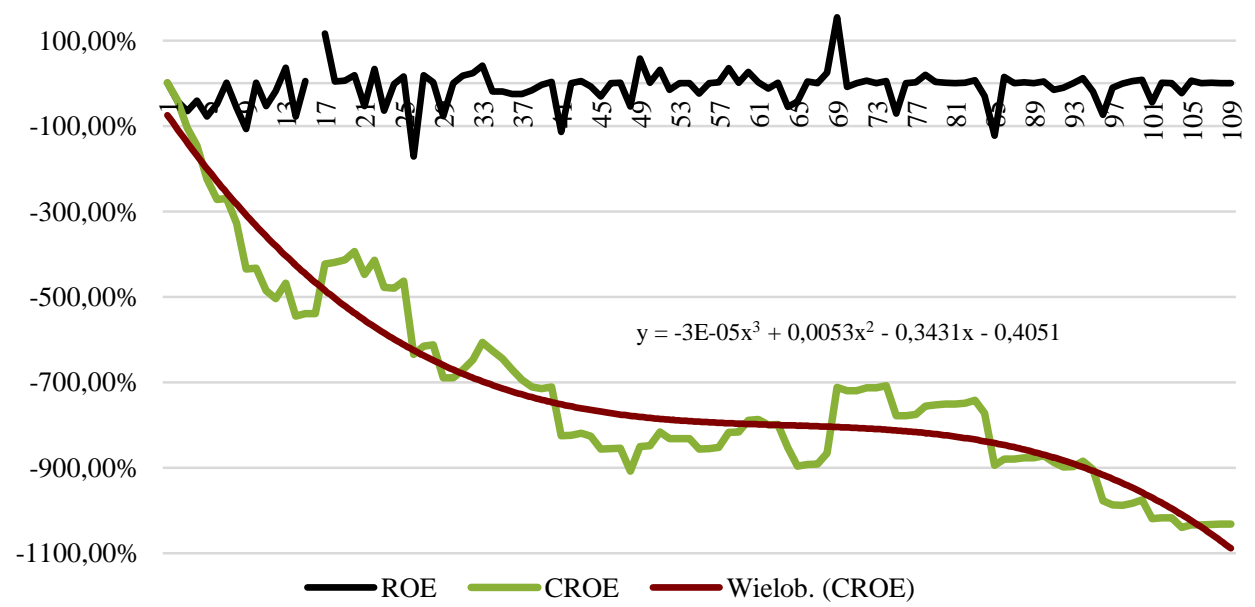

Figure 6. Return on Equity and Cumulative Return on Equity of the banks of Ukraine in 2015

Source: own study based on the data of National Bank of Ukraine, Statistics, The Main Indicators of the Activity of Banks of Ukraine (official website).

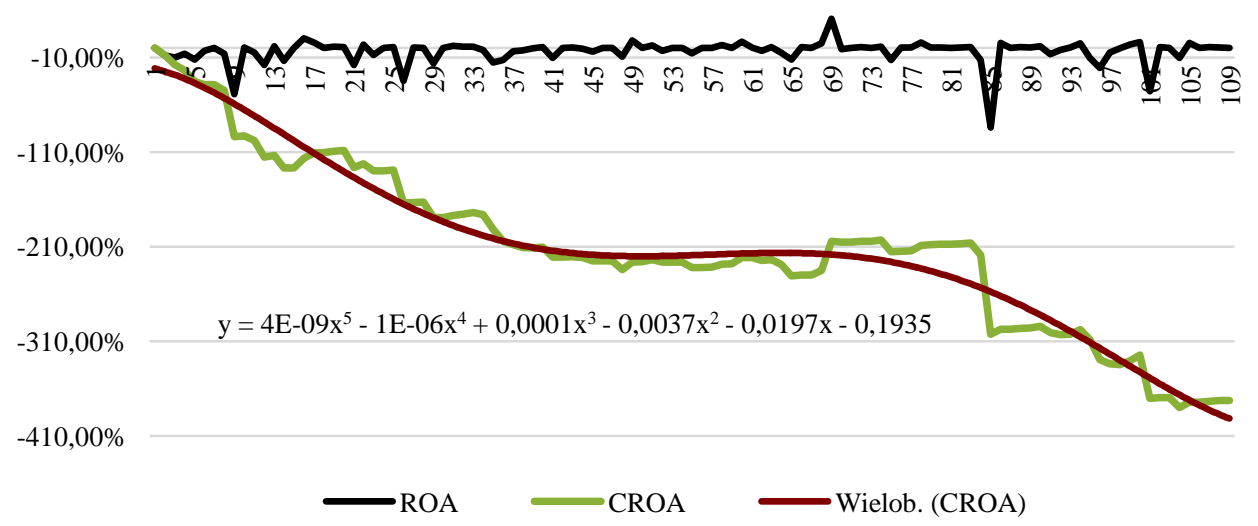

Figure 7. Return on Assets and Cumulative Return on Assets of the banks of Ukraine in 2015

Source: own study based on the data of National Bank of Ukraine, Statistics, The Main Indicators of the Activity of Banks of Ukraine (official website). 


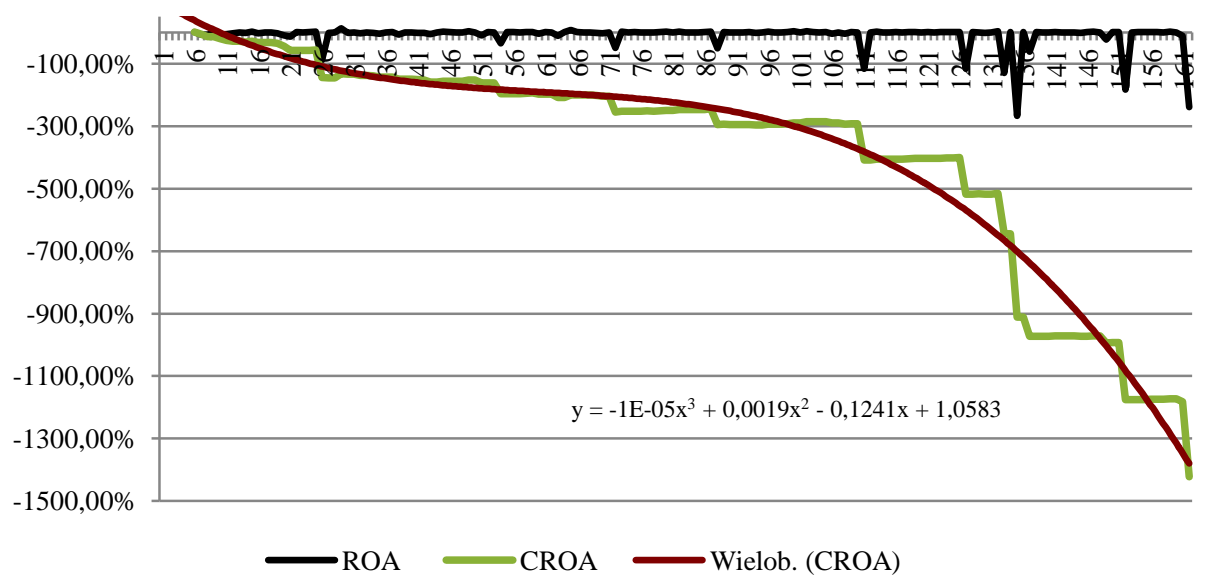

Figure 8. Return on Assets and Cumulative Return on Assets of the banks of Ukraine in 2014

Source: own study based on the data of National Bank of Ukraine, Statistics, The Main Indicators of the Activity of Banks of Ukraine (official website).

So, from one hand the sector's clearance from the insolvent and unscrupulous banks that don't have any business-model and are just the instruments for the shareholders serving is to be done in order to make the system function in favor of economy. But, at the same, time there is a question about the expedience of the massive banks' liquidation. We agree that banking sector of Ukraine is full of serious problems and the central one is the use of banking business not for its functional mission, but for the individual enrichment of the owners. At the same time, the closure of any bank harms the confidence in banking system. The diffusion of the distrust on other financial intermediaries depends directly on their ability to supply economy with the financial resources - any fails can provoke a serious financial panic.

We think that the revealing and the liquidation of the bad banks in the stable environment especially if they are identified in time is much more positive signal than negative. But, taking into consideration social and economic situation in Ukraine, deep depressive state of the Ukrainian society the banks' liquidation especially system banks, from our point of view is a wrong decision. We think that the reason of such active liquidation is a absence of the institute responsible for the prudential diagnostic of the bank's problems and the liquidation of the identified activity faults, but not a bank itself. 


\section{CONCLUSIONS}

So, while researching the influence of the current transforming processes in banking sector of Ukraine we have defined some positive and negative aspects. On the one hand, the clearance of the banking sector has resulted on its aggregated profitability that now depends on the performance of each bank. At last we don't have inoperative banks which haven't any business-model. It will strengthen the productivity of the monetary instruments of the central bank, their influence on the real economy. But at the same time there is a stable tendency for the banking business' concentration increasing, especially on the deposit market of the householders. In order to minimize its negative impact on the banking system stability it's important to implement differential banking supervision approach in accordance with an institution's individual risk, its significance for the system's stability.

\section{REFERENCES}

Berger Allen N., Demirgüç-Kunt A., Levine R., Haubrich Joseph G., 2003, Bank concentration and competition: An evolution in the making, http://siteresources.worldbank.org/DEC/ Resources/84797-1114437274304/jmcb_intro_final.pdf.

Hay D. A., 1991, Industrial economics and organization: Theory and evidence, 2 edition, Oxford University Press, Oxford.

Hirschman A. O., 1964, The paternity of an index, „The American Economic Review”, vol. 54(5).

Laeven L., Ratnovski L., Tong H., 2014, Bank size and systemic risk, IMF Stuff Discussion Note, $\mathrm{SDN} / 14 / 04$

Kapoor S., 2009, A simpler, smaller, safer, more diverse and more stable banking system is what we need!, http://re-define.org/blog/wed-06202012-0925/how-design-good-banking-system.

The complex program of the financial sector of Ukraine development until 2020, 2015, National Bank of Ukraine, https://bank.gov.ua/doccatalog/document?id=18563297.

Tirole J., 1988, The theory of industrial organization, MIT Press, Cambridge, MA.

Unkovs'ka T. E., Demchuk N. I., 2013, Is it possible the economic miracle in Ukraine?, „Economica Ukrainy”, no. 625(12).

Soto H. U., 2008, Money, bank credit, and economic cycles, Sotsium, Chelyabinsk.

\section{PROCESY TRANSFORMACYJNE W SEKTORZE BANKOWYM UKRAINY: PRZYCZYNY I SKUTKI}

\section{Streszczenie:}

Artykuł jest poświęcony badaniu przesłanek i skutków procesów transformacyjnych w sektorze bankowym Ukrainy, ich wpływu na poziom jego wydajności, stabilności i znaczenie dla gospodarki realnej. Uzasadniono, że w chwili obecnej sektor bankowy Ukrainy istotnie osłabił swoje znacze- 
nie w zakresie stymulacji ekonomicznego rozwoju kraju. Stwierdzono, że działania regulatora w sprawie oczyszczenia sektoru bankowego od złych, niesumiennych banków, z jednej strony zwiększyło jego wrażliwość do działania instrumentów pieniężnych, a więc zrobiło jego stan łatwiejszym w zarządzaniu i bardziej prognozowanym. Z innej strony, masowa likwidacja banków spowodowała szybki wzrost poziomu jego skoncentrowania, co przede wszystkim odzwierciedliło się na ponownym podziale depozytów gospodarstw domowych.

Słowa kluczowe: sektor bankowy, koncentracja, efektywność, dochodowość. 